\title{
A case of Bartter's syndrome associated with nephrocalcinosis presenting with tetany
}

\author{
Bülent Ataş, Hüseyin Çaksen, Ŏguz Tuncer, Ercan Kırımi, \\ Şükrü Arslan, Mehmet Erol, Sevil Arl Yuca
}

Department of Pediatrics, Yüzüncü Yll University Faculty of Medicine, Van, Turkey

\begin{abstract}
A 10-year-old boy was admitted to hospital with a 3 month history of intermittent spasms of the wrists and ankles, and twitching of the eyelids. He also had polyuria, polydipsia, nocturnal enuresis, fatigue and constipation since he was a toddler. Physical examination revealed normal blood pressure, myokymia on the right eyelid and bilateral carpopedal spasms. Laboratory investigation revealed hypocalcemia, hypokalemia, increased plasma renin and aldosterone, hypercalciuria, metabolic alkalosis, and bilateral medullary nephrocalcinosis. Cranial computed tomography was normal. Based on the clinical and laboratory findings he was diagnosed as having Bartter's syndrome, which is characterized by hypochloremia, hypokalaemia and metabolic alkalosis associated with potassium renal leakage, with normal blood pressure despite increased plasma renin activity. It is well known that tetany is not uncommon in the neonatal form of Bartter's syndrome and nephrocalcinosis is usually not present in the classic form. Interestingly, our patient had both the clinical manifestations of the neonatal form and of the classic form of Bartter's syndrome. In conclusion, we would like to emphasize that both the clinical manifestations of neonatal and classic forms of Bartter's syndrome (as an overlapping syndrome) might be seen in children
\end{abstract}

Correspondence: Bülent Ataş, M.D.,

Halil ağa mah. Melen Cad. Site blokları. G Blok,

No: 5. Van, Turkey.

Tel: 09043221504 70, fax: 0904322150479 .

E-mail: bulentatas@hotmail.com

Received: July 31, 2003.

Revised: October 04, 2003.

Accepted: November 01, 2003. and that Bartter's syndrome should also be considered in children with tetany as in our case. (J Pediatr Neurol 2004; 2 (1): 45-47).

Key words: nephrocalcinosis, tetany, hypocalcemia, hypokalemia.

\section{Introduction}

Bartter's syndrome (BS) is a well described but uncommon disease characterized by hypochloremia, hypokalaemia and metabolic alkalosis associated with potassium renal leakage and normal blood pressure despite increased plasma renin activity (1-3). A severe form of BS may afflict newborns. It is characterized by polyhydramnios, prematurity, dehydration secondary to marked urinary sodium, potassium and water loss, and growth failure; hypercalciuria and nephrocalcinosis are common. Young children typically present with growth failure, muscle weakness, constipation, and polyuria. Older children have muscle weakness or cramps and carpopedal spasms (4). The estimated incidence of $\mathrm{BS}$ is $1.7 / 100,000$ live births (5). Herein, we present a child who was admitted with manifestations of tetany and diagnosed as having BS associated with nephrocalcinosis. His findings were atypical, with the clinical manifestation of both the neonatal form and the classic forms of BS.

\section{Case Report}

A 10-year-old boy was admitted with a 3-day history of spasms of the wrists and ankles, and twitching of the eyelids. These complaints, which were lasted 24 or 48 hours, were first noted 3 months previously, with spasm attacks recurring 2-3 times per week. He was not examined by a physician, because spasm attacks subsided spontaneously. He was admitted to our Emergency Department, because the latest attack did persist. On questioning, he had polyuria, polydipsia, nocturnal enuresis, 
46

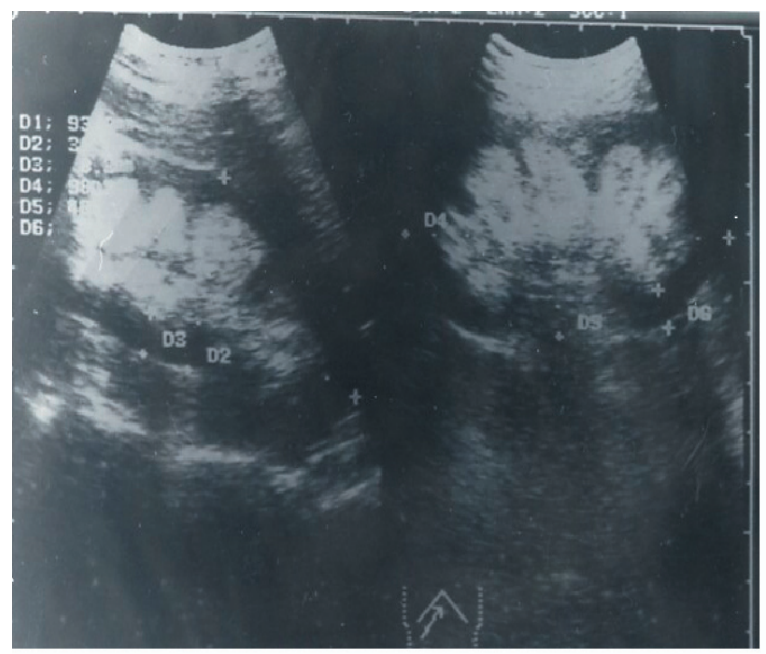

Figure 1. Renal ultrasonography showing bilateral widespread calcification of the medulla extending to the cortical regions.

fatigue and constipation since toddler age. Polyhydramnios was not noted during pregnancy and his developmental milestones were normal. The family history was also unremarkable.

Physical examination revealed body temperature was $36.9{ }^{\circ} \mathrm{C}$; pulse rate $132 / \mathrm{min}$; respiratory rate $32 /$ min; and arterial tension $120 / 80 \mathrm{mmHg}$. The weight and height were $25 \mathrm{~kg}$ and $128 \mathrm{~cm}$, respectively (both between $3^{\text {rd }}-10^{\text {th }}$ percentile). His general condition was good. Myokymia was diagnosed on the right eyelid. He also had fasciculations of his tongue and of muscles of his legs, and bilateral carpopedal spasms. No muscle weakness was noted. The remainder of the physical findings was normal.

On admission urinary analysis revealed $\mathrm{pH}$ was 7.5 ; specific gravity 1.010 ; and normal urinary sediment. Urinary sodium level was $82 \mathrm{mmol} / \mathrm{L}$ (Normal: 20-40 $\mathrm{mmol} / \mathrm{L}$ ); potassium $23 \mathrm{mmol} / \mathrm{L}$ (Normal: < $20 \mathrm{mmol} / \mathrm{L}$ ); chloride $60 \mathrm{mmol} / \mathrm{L}$ (Normal: 20-40 $\mathrm{mmol} / \mathrm{L}$ ); calcium/creatinine ratio 1.08 (Normal: < 0.21); urinary calcium $5.3 \mathrm{mg} / \mathrm{kg}$ / $24 \mathrm{hr}$ (Normal: $<4 \mathrm{mg} / \mathrm{kg} / 24 \mathrm{hr}$ ). Routine blood analysis disclosed; hemoglobin was $14.9 \mathrm{~g} / \mathrm{dL}$; leukocyte count $9,700 / \mathrm{mm}^{3}$; platelet count 586,000 / $\mathrm{mm}^{3}$; and erythrocyte sedimentation rate $20 \mathrm{~mm} /$ h. Serum electrolytes, renal and liver function tests were as follows; blood glucose level was 125 $\mathrm{mg} / \mathrm{dL}$; serum sodium $136 \mathrm{mEq} / \mathrm{L}$; potassium 2.9 $\mathrm{mEq} / \mathrm{L}$; chloride $91 \mathrm{mEq} / \mathrm{L}$; blood urea nitrogen $10 \mathrm{mg} / \mathrm{dL}$; creatinine $0.7 \mathrm{mg} / \mathrm{dL}$; magnesium 1.7 $\mathrm{mg} / \mathrm{dL}$; calcium $6.9 \mathrm{mg} / \mathrm{dL}$; phosphorus $1.3 \mathrm{mg} / \mathrm{dL}$; uric acid $3.1 \mathrm{mg} / \mathrm{dL}$; aspartate aminotransferase 36 $\mathrm{U} / \mathrm{L}$; alanine aminotransferase $53 \mathrm{U} / \mathrm{L}$; alkaline phosphatase $344 \mathrm{U} / \mathrm{L}$; total protein $7.4 \mathrm{~g} / \mathrm{dL}$; and albumin $4.3 \mathrm{~g} / \mathrm{dL}$. Blood gas analysis revealed metabolic alkalosis. Serum parathyroid hormone level was $43 \mathrm{pg} / \mathrm{mL}$ (Normal: 12-72 $\mathrm{pg} / \mathrm{mL}$ ), plasma renin activity $25 \mathrm{ng} / \mathrm{mL} / \mathrm{hr}$ (Normal: 0.5 -
$5.9 \mathrm{ng} / \mathrm{mL} / \mathrm{hr}$ ); and aldosterone level $580 \mathrm{pg} / \mathrm{mL}$ (20-240 pg/mL). Urinary and blood amino acids were normal. Electrocardiography was also normal. Renal ultrasonography showed generalized bilateral medullary nephrocalcinosis (Figure 1). Cranial computed tomography was normal. Unfortunately, we could not perform genetic analysis due to lack of laboratory facilities.

The patient was hospitalized to investigate the etiology of hypocalcemia and intravenous calcium was administrated. After initiation of calcium, carpopedal spasms were improved and then serum calcium level became normal . Based on the clinical and laboratory findings he was diagnosed as having BS. During hospitalization calcium was discounted and potassium chloride $(10 \mathrm{~mL}$ by mouth three times a day) was ordered. No spasm attack was noted after initiating potassium chloride. He was discharged from the hospital with potassium chloride supplementation on the $15^{\text {th }}$ day of admission. After 15 months of follow-up, he was symptom-free.

\section{Discussion}

Three forms of BS are identified as follows: 1) Gitelman syndrome or hypocalciuria hypomagnesemia syndrome is a mild form often discovered in childhood or teenagers by reason of tetany. It is a homogeneous disorder related to mutations of the genes encoding the thiazidesensitive sodium-chloride cotransporter located in the distal convoluted tubule. 2) antenatal BS with hypercalciuria and nephrocalcinosis or hyperprostaglandin E syndrome is a severe form, often revealed by hydramnios, prematurity and growth delay. It is related to mutations of two types of genes encoding for transporters of Henle's loop: the bumetanide-sensitive cotransporter $\mathrm{Na}-\mathrm{K}$ $2 \mathrm{Cl}$ (NKCC2) [type I] or the inwardly rectifying potassium channel (ROMK) [type II]. 3) the classical form or type III BS, often revealed by dehydration in the first year of life, is associated with hypomagnesemia in $20 \%$ of cases and normal or increased calciuria. This form is related to mutations of CLCNKB gene encoding for a chloride channel in Henle's loop. This classification, in part related to the demonstration of mutations in the genes encoding for tubular chloride or potassium channels, does not fit all cases, and overlapping syndromes are frequent $(2,3)$.

Previously, three genes (SLC12A2, the sodiumpotassium-chloride co-transporter; KCNJ1, the ROMK potassium ion channel; $\mathrm{ClC}-\mathrm{Kb}$, the basolateral chloride ion channel) had been identified as causing antenatal and 'classic' Bartter syndrome. Two additional genes have now been identified. Barttin is a beta-subunit that is required for the 
trafficking of CLC-K (both $\mathrm{ClC}-\mathrm{Ka}$ and $\mathrm{ClC}-\mathrm{Kb}$ ) channels to the plasma membrane in both the thick ascending limb and the marginal cells in the scala media of the inner ear that secrete potassium ionrich endolymph. Loss-of-function mutations in barttin thus cause BS with sensorineural deafness (6).

Our patient had tetany, polyuria, polydipsia, nocturnal enuresis, fatigue, constipation, normal blood pressure, hypocalcemia, hypokalemia, increased plasma renin and aldosterone concentrations, hypercalciuria, metabolic alkalosis, and bilateral medullary nephrocalcinosis. According to the classification mentioned above, he had both the clinical manifestations of neonatal form and classic form of BS. Because we could not analyze NKCC2 or ROMK or $\mathrm{ClC}-\mathrm{Kb}$ gene mutation, a definite classification of our patient could not be performed. Our case may be an unusual form of classic BS or neonatal form of BS, but most probably an overlapping syndrome.

Tetany, a state of hyperexcitability of the central and peripheral nervous systems, results from abnormal concentrations of ions in the fluid bathing nerve cells. These abnormalities may include decreases of hydrogen (alkalosis), calcium, or magnesium. A decreased potassium can prevent tetany despite low calcium concentrations; a rising potassium can precipitate tetany in a patient with low calcium. A range of ionic concentrations exists at which tetany can be latent of manifest (7). Our patient had hypocalcemia as well as hypokalaemia; therefore, the symptoms of tetany did not appear until 10 years of age.

BS must be differentiated from licorice abuse, laxative or diuretic use, persistent vomiting or diarrhea, pyelonephritis, and diabetes insipidus. Several of these are associated with hypovolemia, which results in a low urinary chloride level, whereas BS is associated with an elevated level. BS may also be confused with Gitelman syndrome. Both disorders are associated with hypokalemia, renal potassium wasting, activation of the renin-angiotensin-aldosteron axis, and normal blood pressure. Patients with BS have normal to decreased serum magnesium levels, normal urinary magnesium excretion, and normal to increased calcium excretion; patients with Gitelman syndrome have hypomagnesemia, increased urinary magnesium, and decreased calcium excretion (4). Our patient's clinical and laboratory findings were completely consistent with BS.

Although most patients with BS present with growth failure as in the series of Abdel-al et al. (5) tetany as a sole manifestation as in our case has also been reported in the literature $(1,3-5,8)$. In conclusion, we would like to emphasize that both the clinical manifestations of neonatal form and classic form of BS as an overlapping syndrome might be seen in the same patient and BS should also be considered in children with tetany as in our case.

\section{References}

1. Taylor AJ, Dornan TL. Successful treatment of short stature and delayed puberty in congenital magnesium-losing kidney. Ann Clin Biochem 1993; 30: 494-498.

2. Vantyghem MC, Douillard C, Binaut R, Provot F. Bartter's syndromes. Ann Endocrinol (Paris) 1999; 60: 465-472 (in French).

3. Peco-Antic A, Dudic S, Marsenic O, Zivic G. Bartter's syndrome: new classification, and old therapy. Srp Arh Celok Lek 2001; 129: 139-142 (in Serbian).

4. Bergstein JM. Bartter syndrome. In: Behrman RE, Kliegman RM, Jenson HB (eds). Textbook of Pediatrics $\left(16^{\text {th }}\right.$ ed). Philadelphia: WB Saunders, 2000, pp 1601-1602.

5. Abdel-al YK, Badawi MH, Yaeesh SA, et al. Bartter's syndrome in Arabic children: review of 13 cases. Pediatr Int 1999; 41: 299-303.

6. Hebert SC. Bartter syndrome. Curr Opin Nephrol Hypertens 2003; 12: 527-532.

7. Adelman RD Solhaug MJ. Tetany. In: Behrman RE, Kliegman RM, Jenson HB (eds). Textbook of Pediatrics $\left(16^{\text {th }}\right.$ ed $)$. Philadelphia: WB Saunders, 2000, pp 224-227.

8. Fujihara K, Miyoshi T, Yamaguchi Y, Araki T, Tanaka K. Tetany as a sole manifestation in a patient with Bartter's syndrome and a successful treatment with indomethacin. Rinsho Shinkeigaku 1990; 30: 529-532 (in Japanese). 